\title{
CASUÍSTICA DA EXECUÇÃO CIVIL NEGOCIADA
}

\section{EXAMPLES OF AGREEMENTS ABOUT THE EXECUTION PROCEEDINGS}

\section{Pedro Henrique Nogueira ${ }^{1}$}

\section{RESUMO}

Este artigo trata dos negócios jurídicos processuais no direito brasileiro como instrumento para gestão da execução forçada.

Palavras-chave: Negócios jurídicos processuais; Gestão do processo; Execução.

\section{ABSTRACT}

This article examines the contract procedure as a way of the executionproceedings management in the Brazilian law

Keywords: Contract procedure; Case management; Execution proceedings.

\section{INTRODUÇÃO}

O procedimento executório, no direito brasileiro, é campo muito fértil para celebração de negócios jurídicos processuais, servindo aos mais variados propósitos das partes. Buscaremos demonstrar algumas maneiras de utilizar a negociação processual para que as partes, consensualmente, consigam gerenciar a execução a fim de adaptá-la e promover tanto uma utilização mais eficiente do procedimento executivo, com estipulação de técnicas para sua aceleração, quanto um uso mais seguro da execução forçada em benefício do executado, estabelecendo certos limites à intervenção na esfera jurídica do devedor.

\section{FUNDAMENTOS PARA A NEGOCIAÇÃO DA EXECUÇÃO NO DIREITO BRASILEIRO}

É possível utilizar, amplamente, a negociação processual, quer para promover a celeridade e a eficiência da execução forçada, quer para limitar a atividade executiva, restringindo a prática de atos de constrição, quer, ainda, para regular como os atos executórios haverão de ser praticados, conferindo assim maior previsibilidade para os envolvidos.

Do ponto de vista do direito positivo brasileiro, há três principais justificativas para ratificar a afirmação de que a execução é campo propício para a negociação processual: a) a norma fundamental do respeito ao autorregramento da vontade no processo; b) a cláusula geral de atipicidade da negociação processual; c) o regime de disponibilidade da execução forçada.

\subsection{A NORMA FUNDAMENTAL DO RESPEITO AO AUTORREGRAMENTO DA VONTADE NO PROCESSO}

\footnotetext{
${ }^{1}$ Pós-Doutor pela Universidade Federal de Pernambuco (UFPE). Doutor em Direito pela Universidade Federal da Bahia (UFBA) e Mestre pela Universidade Federal de Alagoas (UFAL). Professor no mestrado e na graduação da Universidade Federal de Alagoas (UFAL). Membro fundador da Associação Norte e Nordeste de Professores de Processo (ANNEP), do Instituto Brasileiro de Direito Processual (IBDP) e do Instituto Iberoamericano de Direito Processual. Advogado e consultor.
} 


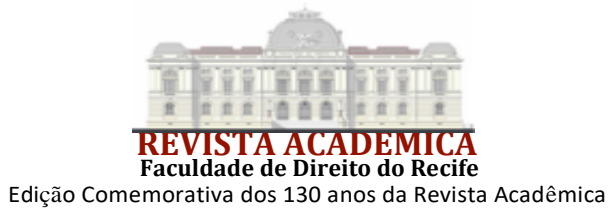

Para além da constatação de que o CPC/15 passou a prever diversas modalidades de negócios processuais típicos e a consagração de ampla liberdade para negociação processual atípica, é necessário levar em consideração a positivação em nosso ordenamento da norma fundamental de respeito ao autorregramento da vontade no processo ${ }^{2}$, expressamente consagrada no art. $3^{\circ}, \S 2^{\circ}$, ao prever que "O Estado promoverá, sempre que possível, a solução consensual dos conflitos." O Código também enuncia, no $\S 3^{\circ}$ do art. $3^{\circ}$, que "A conciliação, a mediação e outros métodos de solução consensual de conflitos deverão ser estimulados por juízes, advogados, defensores públicos e membros do Ministério Público".

Da conjugação desses dois enunciados normativos podem-se extrair, analiticamente: (a) uma norma jurídica que tem como destinatário o juiz, estabelecendo um dever geral de promover a autocomposição, além de (b) uma norma jurídica destinada aos alguns sujeitos do processo (juízes, advogados, defensores públicos e membros do Ministério Público), determinando o estímulo à autocomposição.

O dever geral de promover a autocomposição abrange um dever positivo de priorizar a solução autocompositiva. $\mathrm{O}$ ordenamento jurídico brasileiro se estruturou para dar primazia à autocomposição. A solução adjudicada deve ser sempre residual.

Além disso, o dever geral de promover a autocomposição também engloba um dever negativo, uma imposição de abstenção. O juiz não pode interferir nas soluções autocompositivas arranjadas pelas partes.

O respeito ao autorregramento da vontade, como núcleo da norma do art. $3^{\circ}, \S 2^{\circ}$ do CPC/15, supõe um espaço de liberdade ${ }^{3}$ para as partes encontrarem soluções autocompositivas, sem interferência do órgão jurisdicional. Isso, evidentemente, não significa que o juiz deva silenciar sobre todo e qualquer acordo ou negócio jurídico que lhe seja apresentado, mas sim que o seu modo de atuação estará limitado: a função do juiz em face da autocomposição será de controlar a validade do ato.

A autocomposição, examinada enquanto fenômeno do processo ou para o processo, possui uma dimensão substancial, quando vertida para os direitos litigiosos (v.g. acordos e transações celebrados pelas partes para pôr fim ao litígio), e uma dimensão processual, centrada na busca de consenso em torno do procedimento ou de situações jurídicas processuais (aqui o espaço para os negócios jurídicos processuais).

A negociação processual, no sistema do CPC/15, constitui apenas uma das dimensões da autocomposição, que, por sua vez, deve ocorrer no contexto do respeito ao autorregramento da vontade. Trata-se de norma fundamental do processo civil brasileiro, que se estrutura a partir dela.

Impor o respeito ao autorregramento da vontade não significa abstenção absoluta do juiz em face dos negócios jurídicos processuais; muda, contudo, a função a ser desempenhada pelo órgão jurisdicional, que se transforma num facilitador da negociação, possuindo o dever de implementar e assegurar o cumprimento do que foi convencionado pelas partes e também de controlar a validade das convenções ${ }^{4}$.

${ }^{2}$ DIDIER JR., Fredie. Princípio do respeito ao autorregramento da vontade no processo civil. In: CABRAL, Antonio; NOGUEIRA, Pedro Henrique (org.). Negócios Processuais. Salvador: Juspodivm, 2015. p. 22.

${ }^{3}$ FREDIE DIDIER JR., de maneira precisa, identifica a conexão entre a liberdade como direito fundamental consagrada na Constituição brasileira e os espaços de autonomia da vontade que devem existir para que se tenha um processo devido (due process): “Um processo que limite injustificadamente o exercício da liberdade não pode ser considerado um processo devido. Um processo jurisdicional hostil ao exercício da liberdade não é um processo devido, nos termos da Constituição brasileira." (DIDIER JR., Fredie. Princípio do respeito ao autorregramento da vontade no processo civil. In: CABRAL, Antonio; NOGUEIRA, Pedro Henrique (org.). Negócios Processuais. Salvador: Juspodivm, 2015. p. 22).

${ }^{4}$ Com razão Delosmar DE MENDONÇA Neto e LuCIANo GuimarÃes, ao afirmarem: “o juiz se vincula ao celebrado pelas partes em matéria de procedimento ou às disposições relacionadas aos ônus, poderes e deveres processuais, cabendo-lhe, tão somente, promover a implementação dos meios necessários ao cumprimento do que fora acordado" (MENDONÇA NETO, Delosmar de; GUIMARÃES, Luciano Cezar Vernalha. Negócio jurídico processual, direitos que admitem a autocomposição e o pactum de non petendo. Revista de Processo, n. 272. São Paulo, p. 419-439, out. 2017). 
Por isso, o regime da negociação processual no ordenamento jurídico brasileiro, a partir do $\mathrm{CPC} / 15$, deve ter como ponto de partida o dever geral de promover a autocomposição $\left(\operatorname{art} .3^{\circ}, \S 2^{\circ}\right.$ e art. $\left.139, V^{5}\right)$.

\subsection{A CLÁUSULA GERAL DE ATIPICIDADE NA NEGOCIAÇÃO PROCESSUAL}

Não se pode negar que o art. 190 , caput, do CPC/2015 ${ }^{6}$ representa uma grande novidade no direito brasileiro: por meio dele foi atribuída às partes e aos sujeitos em geral o poder jurídico de disciplinarem, por meio de negócios jurídicos, de maneira ampla, o próprio processo.

O dispositivo é resultado do uso da técnica legislativa da cláusula geral, caracterizada por revelar disposições normativas que utilizam em sua linguagem uma tessitura aberta e vaga, promovendo a abertura do sistema. O CPC/2015 (art. $3^{\circ}, \S 3^{\circ}$ ) estabelece um dever geral de estímulo à autocomposição. A negociação sobre o processo constitui uma das formas possíveis de solução consensual dos litígios, valorizando a possibilidade de acordo sobre o modo de resolver os conflitos, especialmente quando não seja possível a sua própria resolução por via amigável.

Do ponto de vista da Ciência do Processo, pelas possibilidades de arranjos que o art. 190 do CPC/2015 permite acomodar, restará infrutífera a recusa doutrinária ao conceito de negócio jurídico processual, pois, mesmo para os que trabalham com concepções voluntaristas de negócio jurídico, será possível identificar atos processuais em que as partes escolham os respectivos efeitos.

A partir do art. 190 do CPC/2015 é possível extrair a possibilidade de celebração de negócios jurídicos processuais atípicos ${ }^{7}$, isto é, para além daqueles já expressamente previstos no sistema. E mesmo no âmbito da atipicidade negocial, as partes podem (a) negociar sobre o procedimento (acordos de procedimento), assim como $(b)$ negociar sobre ônus, faculdades e direitos e também sobre seus deveres no processo $^{8-9}$.

A escolha do procedimento pode ser um negócio jurídico unilateral feito pelo autor ao ajuizar a demanda. Não raro estará o demandante autorizado pelo sistema a optar por um dentre dois ou mais procedimentos admissíveis para tutela do direito subjetivo material afirmado (para se pleitear o reconhecimento de um crédito fiscal pode-se ajuizar uma "ação" ordinária, mas se revela admissível também o ajuizamento de mandado de segurança, v.g.). Esse ato de escolha configura um negócio jurídico processual unilateral. Para as hipóteses em que pelo sistema é dado ao

5 “Art. 139. O juiz dirigirá o processo conforme as disposições deste Código, incumbindo-lhe:[...]V - promover, a qualquer tempo, a autocomposição, preferencialmente com auxílio de conciliadores e mediadores judiciais;"

6 “Art. 190. Versando o processo sobre direitos que admitam autocomposição, é lícito às partes plenamente capazes estipular mudanças no procedimento para ajustá-lo às especificidades da causa e convencionar sobre os seus ônus, poderes, faculdades e deveres processuais, antes ou durante o processo."

${ }^{7}$ No direito brasileiro, pode-se admitir a existência de negócios processuais típicos, quando o respectivo modelo já vier previamente estabelecido (v.g. acordo para suspensão do processo, art. 313, II), bem como de negócios processuais atípicos, quando não houver previsão, mas abertura do sistema para a estipulação negocial como fruto do exercício do poder de autorregramento da vontade. Esses negócios podem resultar da estipulação e configuração de novos arranjos negociais, ou de combinação ou fusão de negócios típicos.

${ }^{8}$ No mesmo sentido o enunciado 257 do FPPC: "O art. 190 autoriza que as partes tanto estipulem mudanças do procedimento quanto convencionem sobre os seus ônus, poderes, faculdades e deveres processuais."

9 Na Alemanha, há quem classifique os contratos de procedimento em duas espécies: a) contratos de procedimento em sentido estrito, nos quais as partes acordam alterar ou afastar regras do procedimento, ou, até mesmo, criar um novo regramento; e b) contratos que criam obrigações relativas ao procedimento, por meio dos quais a parte se compromete a adotar um certo comportamento processual (KERN, Cristopher A. Procedural contracts in Germany. In: CABRAL, Antonio; NOGUEIRA, Pedro Henrique (org.). Negócios Processuais. Salvador: Juspodivm, 2015. p. 181 et seq.). Mantidas as devidas proporções, a tipologia serve para evidenciar que, também no Brasil, é possível dividir os negócios jurídicos entre aqueles que, diretamente, se destinam a regular o procedimento, flexibilizandoo e aqueles que objetivam afetar as situações jurídicas processuais dos sujeitos do processo (ônus, faculdades, deveres, direitos). Essa divisão pode ser extraída do enunciado do caput do art. 190 do CPC/2015. 
demandante optar por um ou outro procedimento ${ }^{10}$ não haveria justificativa para recusar que essa opção fosse estabelecida consensualmente, entre autor e réu.

O caput do art. 190 do CPC/2015 vai além e admite a celebração entre as partes de negócios jurídicos bilaterais (acordos) sobre o procedimento, regulando-o convencionalmente. Trata-se do que alguns denominam de flexibilização procedimental voluntária ${ }^{11}$. Em outros sistemas jurídicos, adota-se o modelo de gestão processual, por meio do qual ao juiz é dado interferir no desenrolar do procedimento a fim de adequá-lo às especificidades do caso concreto ${ }^{12}$ (case management). $\mathrm{O}$ art. 190, caput, do CPC/2015 admite a adaptação procedimental, mas não a estabelece como resultado de um ato unilateral do juiz e sim como fruto do consenso.

Os acordos de procedimento valorizam o diálogo entre o juiz e as partes, conferindo-lhes, quando necessário e nos limites traçados pelo próprio sistema, a condição de adaptar o procedimento para adequá-lo às exigências específicas do litígio; trata-se de instrumento valioso para a construção de um processo civil democrático. Podem ser classificados em: (a) acordos de procedimento estáticos e $(b)$ acordos de procedimento dinâmicos, conforme a convenção preveja ou não um regramento diferenciado para o rito ${ }^{13}$.

Os negócios jurídicos bilaterais que recaem sobre o rito, denominados de acordos de procedimento, podem se restringir a uma simples escolha das partes quanto a um procedimento previamente estabelecido na lei; são acordos estáticos.

Por outro lado, as partes podem, exercitando as faculdades que decorrem da incidência do art. 190 do $\mathrm{CPC} / 2015$, ajustar o procedimento de acordo com seus interesses, seja criando um novo rito, seja restringindo fases, seja limitando prazos, meios de prova, ou a própria forma dos atos do processo. Aqui temos os acordos dinâmicos.

O termo "especificidades da causa" posto no enunciado normativo do art. 190 do CPC/2015 está a evidenciar as circunstâncias que as próprias partes convencionam como relevantes para conferir um tratamento diferenciado ao procedimento. São as partes ou figurantes do negócio jurídico que elegem as especificidades e a partir delas acordam ajustes procedimentais. A forma de condução do processo passa a poder ser definida consensualmente, tornando-se as partes artífices da eficiência processual, em termos quantitativos ou qualitativos ${ }^{14}$. Os acordos (bilaterais ou plurilaterais) sobre matéria processual são ferramentas de gestão do processo $^{15}$.

Ao lado dos acordos de procedimento, o art. 190 do CPC/2015, caput, também permite a celebração de negócios jurídicos tendo por objeto ônus, faculdades, poderes e deveres processuais,

10 Outro exemplo de negócio jurídico processual de escolha de procedimento está no acordo entre os litigantes sobre a conversão do processo de inventário para arrolamento sumário (CPC/2015, art. 659).

11 GAJARDONI, Fernando. Flexibilização Procedimental. São Paulo: Atlas, 2008. p. 215

12 Para uma exposição criteriosa do modelo de case management no direito inglês, conferir: ALMEIDA, Diogo Assumpção Rezende de. O case management inglês: um sistema maduro? Revista do Programa de Pós-Graduação em Direito da UFBA, n. 21. Salvador: Fundação Faculdade de Direito da Bahia Editora, 2010, p. 83 et seq. Para uma exposição sobre a expansão da gestão processual na Europa, especialmente na Itália e na França, conferir: ANDRADE, Érico. As novas perspectivas do gerenciamento e da "contratualização" do processo. Revista de Processo, São Paulo, n. 193, p. 168 et seq., mar. 2011.

13 Sobre o assunto: NOGUEIRA, Pedro Henrique. Sobre os acordos de procedimento no processo civil brasileiro. In: CABRAL, Antonio; NOGUEIRA, Pedro Henrique (org.). Negócios Processuais. Salvador: Juspodivm, 2015. p. 92.

14 Se as partes ajustam o procedimento, suprimindo atos ou etapas, restringindo ou otimizando os meios de prova, estarão convencionando o processo e simultaneamente promovendo a eficiência quantitativa. Ao contrário, se o propósito das partes é a obtenção do máximo proveito em termos de eficiência qualitativa, com prestígio à amplitude e maior abrangência da decisão judicial, "o tempo e o custo do processo não podem ser obstáculos para alcançá-la” (JOBIM, Marco Félix. As Funções da Eficiência no Processo Civil Brasileiro. São Paulo: RT, 2018. p. 126).

15 CAMPOS, Eduardo Luiz Cavalcanti. O Princípio da Eficiência no Processo Civil Brasileiro. Rio de Janeiro: Forense, 2018. p. 156. 
sem que desse ajuste, necessariamente, resulte qualquer mudança no procedimento ${ }^{16}(v \cdot g$. um pacto de redução de prazos processuais, ou um pacto prévio de não executar provisoriamente não interfere na estrutura do procedimento).

$\mathrm{O}$ CPC/2015 conferiu livre disponibilidade às partes nesse aspecto, que podem dispor, conforme como lhes seja conveniente, das situações processuais de vantagem que lhe favoreçam, assim como disciplinar como serão cumpridos os respectivos deveres e como serão suportados os seus ônus no processo.

\subsection{O REGIME DE DISPONIBILIDADE DA EXECUÇÃO FORÇADA NO BRASIL}

O Código de Processo Civil de 2015, seguindo a mesma sistemática da codificação anterior ${ }^{17}$, adotou a regra da disponibilidade da execução ${ }^{18}{ }_{-}^{19}$, consagrada expressamente no enunciado do art. 775: "O exequente tem o direito de desistir de toda a execução ou de apenas alguma medida executiva." ${ }^{20}$ A desistência independe da concordância da parte executada ${ }^{21}$.

A execução se desenvolve no interesse do credor, que, por sua vez, tem a liberdade de decidir e abrir mão da prática de atos executivos, expropriatórios ou não, que possam vir a ser praticados no procedimento executório.

Consagra-se o poder de disposição em favor do exequente, quer quanto ao processo, do que lhe resulta o direito subjetivo processual de desistir a qualquer tempo da execução, mesmo depois da citação do executado, quer quanto a abdicar apenas de determinadas medidas executivas. O enunciado normativo se utiliza do termo "execução" ao invés de "processo executivo", do que resulta a plena aplicação dessa regra da disponibilidade a todos os procedimentos executórios (execuções de título extrajudicial e cumprimento de sentença relativos a obrigações de pagar quantia, entregar coisa, fazer e não fazer, pagar prestação alimentícia etc.).

O Código utilizou a expressão "medidas executivas", cujo significado, por ser mais abrangente, alcança tanto os atos executivos propriamente ditos, sub-rogatórios, quanto as medidas executivas de execução indireta ${ }^{22}$. É lícito ao exequente, portanto, abrir mão das multas

16 Sobre o regime jurídico dos negócios jurídicos processuais atípicos: NOGUEIRA, Pedro Henrique. Negócios Jurídicos Processuais. 2. ed. Salvador: Juspodivm, 2017. p. 227 et seq.

$17 \mathrm{O}$ art. 569 do CPC/73 estabelecia: “Art. 569. O credor tem a faculdade de desistir de toda a execução ou de apenas algumas medidas executivas."

18 Trata-se do que a doutrina brasileira costuma designar de princípio da disponibilidade na execução, segundo o qual "a execução tem por única finalidade a satisfação do crédito, de modo que sua razão de ser está relacionada exclusivamente ao interesse e ao proveito do credor, que dela pode dispor." (ZAVASCKI, Teori Albino. Comentários ao Código de Processo Civil. São Paulo: RT, 2003. p. 75. v. 8.). No mesmo sentido: GRECO, Leonardo. O Processo de Execução. Rio de Janeiro: Renovar, 1999. p. 306. v. 1. ; ASSIS, Araken de. Manual da Execução. 18 ed. São Paulo: RT, 2016. p. 147. ; NEVES, Daniel Amorim Assumpção. Manual de Direito Processual Civil. Salvador: Juspodivm, 2017. p. 1065., dentre outros.

19 Seguindo a ideia de disponibilidade da execução, acima exposta, mas entendendo tratar-se de "regra fundamental" da execução (e não um "princípio"), nomenclatura que também nos parece mais adequada: DIDIER JR., Fredie; CUNHA, Leonardo Carneiro da; BRAGA, Paula Sarno; OLIVEIRA, Rafael Alexandria de. Curso de Direito Processual Civil. Salvador: Juspodivm, 2017. p. 87. v. 5.

${ }^{20}$ A exceção ao regime da disponibilidade da execução está posto no parágrafo único do art. 775 do CPC/15:

“Art. 775. [...]

Parágrafo único. Na desistência da execução, observar-se-á o seguinte:

I - serão extintos a impugnação e os embargos que versarem apenas sobre questões processuais, pagando o exequente as custas processuais e os honorários advocatícios;

II - nos demais casos, a extinção dependerá da concordância do impugnante ou do embargante.”

${ }^{21}$ MIRANDA, Pontes de. Comentários ao Código de Processo Civil, X. Rio de Janeiro: Forense, 1976. p. 544. ; DINAMARCO, Cândido Rangel. Instituições de Direito Processual Civil, IV. São Paulo: Malheiros, 2004. p. 801, dentre outros.

22 Como salienta PONTES DE MIRANDA, as "medidas executivas" a serem objeto da desistência são "as medidas que têm por fim a execução de título judicial ou extrajudicial, como a sub-rogação (art. 673), a alienação em praça (art 


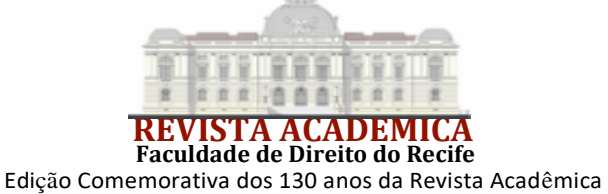

cominatórias (astreintes), da penhora sobre determinados bens, da adjudicação, além de outras medidas conforme adiante exposto.

A desistência das "medidas executivas", inclusive as de caráter coercitivo, não dependente de qualquer consentimento por parte do executado ${ }^{23}$. Trata-se de faculdade de disposição assegurada ao exequente pelo ordenamento jurídico brasileiro, que pode exercê-la unilateralmente.

Isso mostra que no Brasil abriu-se amplo espaço à negociação processual na execução. $\mathrm{O}$ ato jurídico de desistir, seja do processo executório (revogação da demanda), seja de medidas executórias em particular, configura-se um negócio jurídico processual unilateral praticado pelo exequente, por ser desnecessária a concordância do executado; havendo pendência de embargos ou impugnação versando sobre o mérito, a concordância do executado é necessária e, se não houver, a execução será extinta, mas os embargos ou impugnação prosseguem até o julgamento ${ }^{24}$.

Como a disponibilidade é um poder conferido ao exequente, fica clara também a possibilidade de haver acordos processuais (negócios jurídicos processuais bilaterais) celebrados com o executado em torno dela. Se o credor pode dispor da execução, possível seria celebrar negócios jurídicos e obter vantagens legítimas como contrapartida da abdicação a ser negociada.

\section{CASUÍSTICA}

Até aqui foram expostos os fundamentos normativos que justificam a grande amplitude negocial sobre o procedimento executório, ou mesmo apenas sobre alguns atos executivos.

Essa amplitude está alicerçada: a) na norma fundamental de respeito ao autorregramento da vontade no processo em sua dimensão processual $\left(\mathrm{CPC} / 15\right.$, art. $\left.3^{\circ}, \S 2^{\circ}\right)$; b) na cláusula geral da atipicidade de negociação processual (CPC/15, art. 190); e c) na regra de disponibilidade da execução pelo exequente (CPC/15, art. 775).

Examinaremos, doravante, com exemplificação, algumas das hipóteses que ilustram o uso dos negócios jurídicos processuais bilaterais tanto para promover a eficiência da execução, quanto para limitar a prática de atos executivos.

\subsection{ACORDOS PROCESSUAIS PARA CONFERIR MAIOR EFICIÊNCIA À EXECUÇÃO}

O uso de negócios jurídicos processuais bilaterais como instrumento de gestão do procedimento executivo encontra respaldo na cláusula geral de negociação processual.

Aperfeiçoar a execução, seja com a eliminação de atos processuais, seja com a alteração do rito, é objetivo que pode ser alcançado através de acordos feitos entre as partes. Respeitados os limites objetivos para a celebração de negócios jurídicos processuais atípicos ${ }^{25}$, há um enorme campo para que o exequente consiga obter um processo executivo mais eficiente, com maior propensão a gerar o resultado da satisfação do crédito exequendo, conforme a seguir exemplificado.

\subsubsection{ACORDOS COM RENÚNCIA OU RESTRIÇÕES AO BENEFÍCIO DA IMPENHORABILIDADE}

É possível cogitar de negócios jurídicos pré-processuais e processuais que veiculem uma abdicação do devedor da garantia processual de impenhorabilidade. Apesar de o tema ser

732 e parágrafo único), a prisão d devedor (art. 733, $\S 1^{\circ}, 2^{\circ}$ e $3^{\circ}$ )"(MIRANDA, Pontes de. Comentários ao Código de Processo Civil, IX. Rio de Janeiro: Forense, 1976. p. 111).

${ }^{23}$ LIMA, Alcides Mendonça. Comentários ao Código de Processo Civil. Rio de Janeiro: Forense, 1977. p. 188. v. 6. t. 1.

${ }^{24}$ CUNHA, Leonardo Carneiro da. Comentário ao art. 775. In: STRECK, Lenio Luiz; NUNES, Dierle; CUNHA, Leonardo Carneiro da. Comentários ao Código de Processo Civil. São Paulo: Saraiva, 2017. p. 1.039.

25 NOGUEIRA, Pedro Henrique. Negócios Jurídicos Processuais. 2. ed. Salvador: Juspodivm, 2017. p. 240 et seq. 


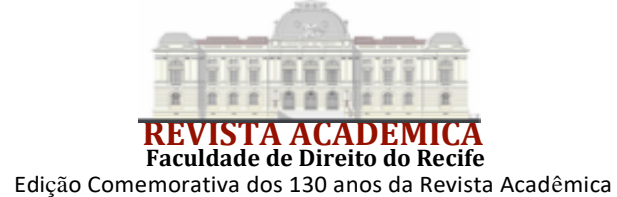

nenhum acordo para exercer a escolha da forma de expropriação, a pactuação traz a vantagem de vincular desde logo o executado à escolha e até dispensar a realização de algumas intimações, especialmente no caso de opção pela adjudicação, como previsto no art. $876, \S 1^{\circ}$ do $\mathrm{CPC} / 15^{29}$ ).

Como se pode observar, esses negócios jurídicos (pré-processuais ou processuais) executivos possuem a virtude de funcionar como técnica de aceleração do procedimento de execução ou do cumprimento de sentença, sobretudo das obrigações de pagar, simplificando a atuação do exequente no processo e ao mesmo tempo restringindo a necessidade de se promover certos atos processuais (tais como: avaliação, intimação da penhora, intimação do pedido de adjudicação).

Por meios desses acordos de procedimento, busca-se o resultado de um maior rendimento da execução, potencializando as possiblidades de satisfação do crédito exequenedo, com o mínimo de dispêndio, em face da redução dos atos processuais a serem praticados.

\subsection{ACORDOS PROCESSUAIS PARA CONFERIR MAIOR PROTEÇÃO AO EXECUTADO}

O uso dos negócios jurídicos bilaterais (pré-processuais e processuais) pode servir também ao propósito de limitar a prática de atos executivos, promovendo maior proteção e segurança jurídica $^{30}$ ao executado. Trata-se de modalidade de gestão convencional da execução, mas com o propósito de fortalecer as posições jurídicas do devedor, sem que disso resulte, necessariamente, a perda de eficiência ou mesmo o sucesso da execução forçada.

Não se deve olvidar que o regime jurídico da execução, no direito brasileiro, está alicerçado na regra da disponibilidade. Desse modo, abrem-se várias possibilidades para que credor e devedor celebrem acordos processuais envolvendo medidas executivas.

\subsubsection{ACORDOS PARA AMPLIAÇÃO DAS HIPÓTESES DE IMPENHORABILIDADE}

O CPC/15, no art. 832, exclui da execução os bens impenhoráveis e no art. 833 apresenta uma relação não exaustiva de bens insusceptíveis de penhora.

Não há nenhuma vedação no ordenamento jurídico a que as partes estabeleçam, consensualmente, em negócios pré-processuais ou processuais, novas categorias de bens impenhoráveis ( $v . g$. impenhorabilidade de semoventes presentes ou futuros pertencentes ao devedor), ou que estabeleçam especificadamente um bem determinado como impenhorável, mesmo quando pertencente a uma classe de bens não protegidos pela impenhorabilidade de origem legal (v.g. pacto para que um determinado automóvel pertencente ao devedor se torne insusceptível de penhora).

O pacto de impenhorabilidade constitui negócio jurídico típico, expressamente admitido pelo art. 833, I do CPC/15. Esse dispositivo inclusive fala de "ato voluntário" a declarar bens "não sujeitos à execução", o que faz subentender a possibilidade dessa ampliação das hipóteses de impenhorabilidade poder ser feita tanto unilateralmente pelo próprio credor ou exequente quanto de forma convencional.

\subsubsection{ACORDOS PARA EVITAR DETERMINADAS CONSTRIÇÕES JUDICIAIS}

29 A dispensa de intimação do executado, quando a adjudicação for estabelecida negocialmente, todavia, não pode afastar a intimação dos terceiros que também possuam legitimidade para adjudicar, nos termos do art. $876, \S 5^{\circ}$ do $\mathrm{CPC} / 15$.

${ }^{30}$ Como observou ANTONIO DO PASSO CABRAL, "os acordos processuais emprestam segurança e previsibilidade ao tráfico jurídico porque incrementam a certeza da aplicação das regras processuais (se as regras legais tivessem que ser aplicadas e interpretadas, o resultado seria incerto)." (CABRAL, Antonio do Passo. Convenções Processuais. Salvador: Juspodivm, 2016. p. 203). 


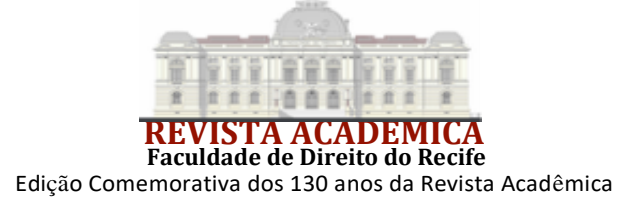

É possível vislumbrar várias possibilidades de negócios jurídicos processuais que limitem ou restrinjam a prática de atos executivos contra o executado.

A premissa fundamental para o tratamento dessa modalidade de negocial processual no direito brasileiro está na regra da disponibilidade da execução, prevista no art. 775 do CPC/15. A execução se desenvolve no interesse do credor, que, por sua vez, possui a liberdade de decidir, unilateralmente, entre executar ou abdicar, total ou parcialmente, da execução ou de meios executivos.

O Estado-juiz não pode impor ou compelir o exequente a executar, ou a adotar essa ou aquela medida executiva que não lhe convenha. Mesmo quando admitida a iniciativa do juiz para deflagrar a execução (v.g. CPC/15, art. 536, caput), eventual desistência posterior vincula o órgão jurisdicional, que nada poderá fazer para dar seguimento a um procedimento executório que já não convenha ao exequente. Por conseguinte, muitas possibilidades se abrem à negociação das medidas executivas em face desse regime jurídico.

Um negócio jurídico pré-processual, v.g., poderá eventualmente conter cláusula que afaste categoricamente a realização do arresto executivo (CPC/15, art. 830) no futuro processo de execução contra o executado quando este não venha a ser prima facie localizado para citação. É medida de preservação do devedor contra medidas executivas altamente danosas, como o bloqueio eletrônico prévio de quantias em dinheiro antes mesmo de sua cientificação ${ }^{31}$ e da oportunidade para pagamento voluntário do débito.

As partes também podem convencionar a não realização de venda do bem penhorado em hasta pública, estipulando-se em contrapartida, por exemplo, que somente será feita a tentativa de expropriação por alienação particular, ou, em caso de insucesso, por meio de adjudicação.

Pelo mesmo motivo, também se revelaria possível um negócio jurídico bilateral para que não houvesse, pelo exequente, a adjudicação do bem penhorado no processo. Trata-se de um pacto para excluir um meio expropriatório; um autêntico mecanismo de gestão consensual da execução.

\subsubsection{ACORDOS PARA AFASTAR A PRISÃO CIVIL E OUTRAS MEDIDAS COERCITIVAS}

A prisão civil, como medida de execução indireta de coerção pessoal, também pode ser negociada no direito brasileiro.

Conquanto possa o juiz decretar de ofício a prisão civil na execução de alimentos, é preciso levar em consideração que o procedimento executivo sempre se desenvolve no interesse do credor (CPC/15, art. 797) e que vigora a regra da plena disponibilidade (CPC/15, art. 775), pela qual é facultado ao exequente desistir da própria execução ou de algumas medidas executivas, diretas ou indiretas, seja de coerção pessoal ou coerção patrimonial.

Tratando-se de alimentos devidos a ex-cônjuge ou ex-companheiro, é lícito ao exequente, que está autorizado a renunciar à pensão alimentícia, promover a execução através do uso exclusivo do meio da expropriação ou do meio do desconto em folha ou remuneração para satisfação do seu crédito. O próprio credor pode pretender preservar a pessoa do devedor por razões morais, pessoais, assim como por interesses patrimoniais, já que o recolhimento do executado ao ergástulo, em certas situações, poderia comprometer a percepção de renda e, por conseguinte, dificultar a satisfação do crédito exequendo ${ }^{32}$ ou a percepção de parcelas vincendas.

Todas as medidas executivas de natureza coercitiva comportam negociação, desde as mais severas e invasivas até as menos restritivas. Nesse sentido, as partes podem: a) estipular que não será feito o protesto da decisão judicial exequenda (CPC/15, art. 517); b) definir negocialmente

31 Segundo decidiu o STJ, "Frustrada a tentativa de localização do executado, é admissível o arresto de seus bens na modalidade on-line" (STJ. AgRg no AREsp 655.318/RJ, Rel. Ministro Marco Aurélio Bellizze, DJe 30/06/2016).

${ }^{32}$ MAZZEI, Rodrigo; NOGUEIRA, Pedro Henrique. Comentários aos arts. 528 a 533. In: ALVIM, Angelica Arruda et. al (Coord.). Comentários ao Código de Processo Civil. São Paulo: Saraiva, 2016. p. 655. 
limites mínimos e máximos de valores para as astreintes ${ }^{33}$; c) estipular a renúncia prévia do exequente as astreintes; d) convencionar que o executado não será incluído em cadastro de inadimplentes $\left(\mathrm{CPC} / 15\right.$, art. $\left.782, \S 3^{\circ}\right)$ etc.

Seguindo o mesmo raciocínio, revela-se perfeitamente lícito às partes negociaram a exclusão de medidas executivas coercitivas, previstas no art. 139 , IV do CPC $/ 15^{34}$. Sem adentrar aqui no problema do âmbito de incidência desse dispositivo, o fato é que alguns dos tribunais brasileiros têm admitido o uso de algumas medidas severas para compelir o devedor a satisfazer o crédito em execução (v.g. apreender passaporte, suspender carteira de habilitação, ou interditar o uso de cartão de crédito etc.).

As partes podem, através de negócios jurídicos pré-processuais e processuais, não só antecipadamente afastar certas medidas coercitivas, como também estipular, consensualmente, que nenhuma medida executiva coercitiva poderá ser utilizada contra o devedor. A disponibilidade da execução alcança medidas de execução direta e indireta.

\section{REFERENCIAS}

ALMEIDA, Diogo Assumpção Rezende de. O case management inglês: um sistema maduro? Revista do Programa de Pós-Graduação em Direito da UFBA, Salvador, n. 21, 2010.

ANDRADE, Érico. As novas perspectivas do gerenciamento e da "contratualização" do processo. Revista de Processo, São Paulo, n. 193, mar. 2011.

ASSIS, Araken de. Manual da Execução. 18 ed. São Paulo: RT, 2016.

CABRAL, Antonio do Passo. Convenções Processuais. Salvador: Juspodivm, 2016. CAMPOS, Eduardo Luiz Cavalcanti. O Princípio da Eficiência no Processo Civil Brasileiro. Rio de Janeiro: Forense, 2018.

CUNHA, Leonardo Carneiro da. Comentário ao art. 775. In: STRECK, Lenio Luiz; NUNES, Dierle; CUNHA, Leonardo Carneiro da. Comentários ao Código de Processo Civil. São Paulo: Saraiva, 2017.

DIDIER JR., Fredie. Princípio do respeito ao autorregramento da vontade no processo civil. In: CABRAL, Antonio; NOGUEIRA, Pedro Henrique (org.). Negócios Processuais. Salvador: Juspodivm, 2015.

33 Em sentido contrário ao aqui defendido: “As partes não podem deliberar, por convenção, que o juiz não utilizará alguns meios de coerção para pressionar o litigante a cumprir uma decisão (não podem, v.g., limitar o valor das astreintes; não podem também impedir ou limitar a aplicação de multas para sancionar a litigância de má-fé). É que o uso da multa pecuniária não só diz respeito a prerrogativas do Estado-juiz para emprestar às suas decisões a efetividade necessária" (DIDIER JR., Fredie; CABRAL, Antonio do Passo. Negócios jurídicos processuais atípicos e execução. Revista de Processo, n. 275. São Paulo, p. 193-228, jan. 2018.). Parece-nos, contudo, que os poderes executivos do juiz para adoção de medidas coercitivas, inclusive astreintes, são instrumentais; estão condicionados à autonomia da vontade do exequente, que pode não querer se beneficiar dessas técnicas, pois (a) a execução se desenvolve no interesse do credor e (b) o exequente possui liberdade para abrir mão de qualquer medida executiva (CPC/15, art. 775).

34 “Art. 139. O juiz dirigirá o processo conforme as disposições deste Código, incumbindo-lhe:

[...]

IV - determinar todas as medidas indutivas, coercitivas, mandamentais ou sub-rogatórias necessárias para assegurar o cumprimento de ordem judicial, inclusive nas ações que tenham por objeto prestação pecuniária;” 
DIDIER JR., Fredie; CABRAL, Antonio do Passo. Negócios jurídicos processuais atípicos e execução. Revista de Processo, São Paulo, n. 275, jan. 2018.

DIDIER JR., Fredie; CUNHA, Leonardo Carneiro da; BRAGA, Paula Sarno; OLIVEIRA, Rafael Alexandria de. Curso de Direito Processual Civil. Salvador: Juspodivm, 2017. v. 5.

DINAMARCO, Cândido Rangel. Instituições de Direito Processual Civil, IV. São Paulo: Malheiros, 2004.

GAJARDONI, Fernando. Flexibilização Procedimental. São Paulo: Atlas, 2008.

GRECO, Leonardo. O Processo de Execução. Rio de Janeiro: Renovar, 1999. v. 1.

JOBIM, Marco Félix. As Funções da Eficiência no Processo Civil Brasileiro. São Paulo: RT, 2018.

KERN, Cristopher A. Procedural contracts in Germany. In: CABRAL, Antonio; NOGUEIRA, Pedro Henrique (org.). Negócios Processuais. Salvador: Juspodivm, 2015.

LIMA, Alcides Mendonça. Comentários ao Código de Processo Civil. Rio de Janeiro: Forense, 1977.v. 6. t. 1.

MAZZEI, Rodrigo; NOGUEIRA, Pedro Henrique. Comentários aos arts. 528 a 533. In: ALVIM, Angelica Arruda et a.l (coord.). Comentários ao Código de Processo Civil. São Paulo: Saraiva, 2016.

MENDONÇA NETO, Delosmar de; GUIMARÃES, Luciano Cezar Vernalha. Negócio jurídico processual, direitos que admitem a autocomposição e o pactum de non petendo. Revista de Processo, São Paulo, n. 272, out. 2017.

MIRANDA, Pontes de. Comentários ao Código de Processo Civil, IX. Rio de Janeiro: Forense, 1976.

MIRANDA, Pontes de. Comentários ao Código de Processo Civil, X. Rio de Janeiro: Forense, 1976.

NEVES, Daniel Amorim Assumpção. Manual de Direito Processual Civil. Salvador: Juspodivm, 2017.

NOGUEIRA, Pedro Henrique. Negócios Jurídicos Processuais. 2. ed. Salvador: Juspodivm, 2017.

NOGUEIRA, Pedro Henrique. Sobre os acordos de procedimento no processo civil brasileiro. In: CABRAL, Antonio; NOGUEIRA, Pedro Henrique (org.). Negócios Processuais. Salvador: Juspodivm, 2015.

ZAVASCKI, Teori Albino. Comentários ao Código de Processo Civil. São Paulo: RT, 2003. v. 8. 